\title{
Pengaruh Kecanggihan Teknologi Informasi, Partisipasi Manajemen, Pengetahuan Manajer Akuntansi terhadap Efektivitas Sistem Informasi Akuntansi
}

(Studi Kasus pada Hotel Berbintang Tiga \& Empat di Kota Semarang)

\author{
DIAN ARUM SASONGKO \\ Account Receivable SPV Hotel Novotel Semarang \\ Jl. Pemuda No.123, Sekayu, Kota Semarang, 50132 \\ Email : paulinadians45@gmail.com
}

Diterima 12 Agustus 2020; disetujui 26 Agustus 2020;

\begin{abstract}
Managers need relevant, accurate, and reliable information just in time in order to make appropriate decisions. By accounting information system, the effectiveness can be achieved. The purpose of this study was to analyze the influence of information technology sophistication, management participation, accounting manager knowledge on accounting information system effectiveness of three stars and four stars hotels in Semarang. The samples were 80 accounting managers with the sampling techniques of purposive sampling. The analysis instrument of this study was multiple linear regression analysis. The result showed that information technology sophistication and management participation did not affect accounting information system effectiveness while accounting manager knowledge had a positive and significant effect on accounting information system effectiveness.
\end{abstract}

Keywords: Information technology sophistication, management participation, accounting manager knowledge, accounting information system effectiveness

\section{PENDAHULUAN}

Latar Belakang. Dewasa ini untuk mencapai kesesuaian yang baik antar aktivitas di perusahaan dibutuhkan pengumpulan data dari setiap aktivitas yang terjadi. Hal ini membuat posisi sistem informasi menjadi penting, karena sistem informasi memiliki fungsi mengumpulkan dan mengintegrasikan data keuangan maupun nonkeuangan. Menggunakan sistem informasi akuntansi dapat membantu organisasi memilih dan mempertahankan strateginya. Sistem informasi akuntansi adalah organisasi formulir, catatan, dan laporan yang dikoordinasi sedemikian rupa untuk menyediakan informasi keuangan yang dibutuhkan oleh manajemen guna memudahkan pengolahan perusahaan (Mulyadi, 2001).

Sistem Informasi akuntansi merupakan salah satu sistem informasi yang di butuhkan oleh perusahaan untuk memudahkan aktivitas pengambilan keputusan berdasarkan data-data dan transaksi keuangan yang terjadi dalam perusahaan. Sistem informasi akuntansi memegang peranan yang cukup vital dalam perusahaan. Agar keputusan 
yang di ambil oleh perusahaan benar dan tepat. Maka sistem informasi akuntansi dalam perusahaan tersebut juga harus benarbenar tepat.

Romney dalam penelitiannya mengemukakan pendapat bahwa sistem informasi akuntansi adalah suatu sistem yang berfokus pada pemahaman cara sistem akuntansi bekerja, bagaimana cara pengumpulan data tentang aktivitas dan transaksi suatu organisasi, bagaimana mengubah data tersebut menjadi informasi yang dapat digunakan pihak manajemen untuk menjalankan organisasi mereka (Romney, 2004).

Laporan keuangan pada umumnya memerlukan teknologi informasi yang bersifat umum dalam yang terdiri dari neraca, perhitungan rugi-laba, laporan arus kas, dan di sertai penjelasannya. (Widjajanto, 2001).

Teknologi informasi merupakan suatu kombinasi dari teknologi yang telah terkomputerisasi dan komunikasi dalam bentuk sistem perangkat lunak dan perangkat keras, salah satu hal yang penting dalam memenangkan persaingan bisnis adalah informasi, terutama informasi keuangan suatu organisasi (Nabizadeh, 2014).

Hasil penelitian Ismail (2009) menyatakan bahwa pengaruh kecanggihan SIA tidak berpengaruh signifikan terhadap efektivitas SIA. Berbeda dengan hasil penelitian yang dilakukan oleh Dwitrayani (2012) dan Ratnaningsih (2014) yang menyatakan bahwa kecanggihan teknologi informasi berpengaruh positif dan signifikan terhadap efektivitas sistem informasi akuntansi.

Tingkat partisipasi yang diberikan oleh manajemen bagi sistem informasi pada organisasi dapat menjadi faktor yang sangat penting dalam menentukan keberhasilan semua kegiatan yang berkaitan dengan sistem informasi (Suwira, 2014).

Dirgayusa (2014) dan Purnomo (2014) menyatakan bahwa partisipasi manajemen memiliki pengaruh yang positif terhadap efektivitas sistem informasi akuntansi keuangan daerah, namun Ferdianti (2017) justru menemukan bahwa dukungan manajemen puncak tidak berpengaruh pada kinerja sistem informasi akuntansi. Lain halnya dengan Fitri (2012) yang menyatakan bahwa partisipasi manajer akuntansi memiliki pengaruh negatif terhadap efektivitas sistem informasi akuntansi.

Para manajer memerlukan satu sistem informasi akuntansi untuk menangani aktivitas operasi rutin sepanjang siklus operasi perusahaan itu. Sistem informasi akuntansi juga mendukung pengambilan keputusan yang tidak rutin pada semua tingkat dari suatu organisasi. Suatu sistem informasi akuntansi juga diperlukan manajer dalam aktivitas perencanaan dan pengendalian. Informasi mengenai anggaran dan biaya standar di simpan oleh sistem informasi, dan laporam dirancang untuk membandingkan angka anggaran dengan jumlah aktual. Pengendalian Internal mencakup kebijakan-kebijakan, prosedurprosedur dan sistem informasi yag digunakan untuk melindungi aset-aset perusahaan dari kerugian atau korupsi dan untuk memelihara keakuratan data perusahaan (Rama, 2008).

Manajer akuntansi juga sering di sebut controller. Controller adalah salah satu manajemen puncak yang berperan aktif dalam perencanaan, pengendalian dan pengambilan keputusan yang akan mempengaruhi perusahaan secara keseluruhan. Pengetahuan manajer memiliki pengaruh positif signifikan pada kesuksesan penerapan sistem informasi akuntansi. Keberhasilan sistem juga tidak terlepas dari keterlibatan manajemen. partisipasi manajer dapat mempengaruhi pengguna untuk mengembangkan perilaku positif yang akan meningkatkan efektivitas sistem. Manajemen perlu me- 
ngontrol dan mengetahui pentingnya sistem informasi sebagai sumber daya strategis perusahaan. Di bidang perhotelan, manajer keuangan selain sebagai penyusun laporan keuangan, juga sebagai pengambil keputusan perusahaan. Oleh karena itu sistem informasi akuntansi sangat di terapkan. (Widjajanto, 2001).

Dalam penelitiannya Kauser, et al (2001) menemukan bahwa pengetahuan manajer akuntansi dan partisipasi manajer dalam pelaksanaan pengembangan sistem informasi akuntansi memiliki hubungan yang kuat dengan efektivitas sistem informasi akuntansi. Demikian pula dengan Komala (2012) yang menemukan bahwa pengetahuan manajer akuntansi berpengaruh positif terhadap efektivitas sistem informasi akuntansi dan memberikan dampak yang signifikan terhadap kualitas informasi. Sistem informasi akuntansi yang dikembangkan, maka guna untuk menciptakan laporan perencanaan yang akurat manajer akuntansi dituntut untuk menguasai penggunaan sistem informasi akuntansi berbasis komputer agar memudahkan dalam pelaksanaanya

Dalam penelitian ini peneliti memilih hotel berbintang tiga dan empat di kota Semarang, karena di anggap mewakili populasi dimana hotel ini memiliki fasilitasfasilitas yang lebih lengkap dari bintang dua dan satu. Hotel berbintang tiga dan empat di kota Semarang sebagian telah menerapkan sistem informasi terintegrasi merupakan sistem yang memproses seluruh proses pelayanan dalam bentuk koordinasi, pelaporan dan prosedur administratif untuk mendukung kinerja dan dapat memperoleh informasi secara cepat, tepat dan akurat.

Tujuan Penelitian. Tujuan penelitian ini adalah untuk menganalisa bagaimana pengaruh kecanggihan teknologi informasi, partisipasi manajemen dan pengetahuan manajer akuntansi terhadap efektivitas sistem informasi akuntansi pada hotel berbintang tiga dan empat di kota Semarang.

\section{TINJAUAN PUSTAKA}

Sistem Informasi Akuntansi. Bodnar \& Hopwood (2007) mendefinisikan sistem informasi sebagai sistem yang mengoptimasi seluruh operasi perusahaan seperti perbankan, sistem transaksi pemrosesan sistem penyimpanan barang dan otomatisasi pabrik. Sedangkan informasi akuntansi, secara garis besar dapat digambarkan sebagai rangkaian aktivitas yang menggambarkan pemrosesan data-data dari aktivitas bisnis pengolahan data-data keuangan perusahaan dengan menggunakan sistem informasi komputer yang terigrasi secara harmonis.

Sistem informasi akuntansi adalah kesatuan struktur-struktur dalam suatu entitas, seperti perusahaan bisnis yang memperkerjakan sumber-sumber daya fisik dan komponen-komponen lain untuk mentransformasi data ekonomi menjadi informasi akuntansi, dengan tujuan untuk memuaskan kebutuhan para pemakai informasi yang bervariasi (Amri, 2010).

Kecanggihan Teknologi Informasi. Sistem ekonomi yang berjalan dewasa ini sangat mengandalkan informasi. Dapat dikatakan bahwa suatu entitas yang kuat secara ekonomis adalah entitas yang menguasai informasi. Dengan informasi, para manajer entitas tersebut dapat mengambil keputusan-keputusan objektif, sehingga hasilnya akan sesuai dengan sasaran yang diharapkan. Akuntan, dan para professional lainnya seperti insiyur, pengacara, ataupun para dokter, sangat memerlukan informasi yang handal. Dengan menggunakan sistem jaringan, para manajer dan profesional 
dalam organisasi akan dapat mengambil keputusan yang tepat, karena yang bersangkutan akan memperoleh berbagai data yang mereka perlukan dari berbagai sumber secara utuh, sehingga keputusan yang akan diambilnya akan didasari pada wawasan yang lebih luas. (Widjajanto, 2001).

Partisipasi Manajemen. Partisipasi manajemen di konseptualiasasikan sebagai keterlibatan dan partipasi eksekutif atau manajemen di bidang teknologi informasi atau sistem informasi (Igbaria et al, 1996). Partipasi manajemen adalah keterlibatan manajemen dalam melaksanakan sistem informasi dan strategi pengembangan untuk sistem informasi yang di implementasikan . Partisipasi manajemen dalam memberikan dukungan merupakan suatu panduan mengenai komitmen dan dukungan atas segala sumber daya yang diperlukan oleh perusahaan (Ann Mooney,2008).

Pengetahuan Manajer Akuntansi. Pengetahuan Manager akuntansi terhadap sistem informasi merupakan faktor yang tidak kalah dalam aplikasi serta pengembangan sistem informasi akuntansi. Menurut penelitian Komara(2012), Manajer akuntansi merupakan eksekutif yang mengkoordinasikan partisipasi manajemen dalam perencanaan dan pengendalian untuk mencapai target perusahaan, khususnya menentukan efektivitas implementasi kebijakan, mengembangkan struktur dan prosedur organisasi.

Sistem Informasi Hotel. Sistem informasi akuntansi pada hotel, menurut Widanaputra, dkk (2009) menyebutkan bahwa sistem informasi akuntansi pada hotel secara teori terdiri dari lima subsistem yaitu (1) Sistem akuntansi utama merupakan sistem akuntansi pada perusahaan jasa yang terdiri atas formulir atau dokumen, jurnal buku besar, buku pembantu, jurnal, bukti transaksi dan laporan. Manajemen meran- cang unsur sistem informasi tersebut menjadi informasi keuangan yang digunakan bagi pihak internal dan eksternal (2) Sistem akuntansi penjualan/piutang merupakan sistem akuntansi yang dirancang untuk mencatat terjadinya transaksi piutang dan berkurangnya piutang. Terjadinya piutang berasal dari penjualan kredit dan menurunnya piutang berasal dari transaksi retur penjualan dan penerimaan kas dari piutang (3) Sistem akuntansi pembelian/hutang, sistem ini dirancang untuk mencatat transaksi terjadi pembelian kredit dan berkurangnya hutang berasal dari trasansaksi retur pembelian dan perlunasan hutang (4) Sistem pencatatan waktu penggajian, sistem ini dirancang untuk menangani transaksi perhitungan gaji dan upah karyawan serta pembayaran (5) Sistem produksi dan biaya produksi, sistem ini di rancang untuk mencatat terjadinya order produksi dan mengawasi persediaan produksi perusahaan.

Penelitian Terdahulu. Penelitian menggenai efektivitas sistem informasi akuntansi telah banyak dilakukan sebelumnya, rangkuman beberapa penelitian terdahulu dapat dilihat pada tabel 1 .

Kerangka Teoritis. Kerangka teoritis dalam penelitian ini dapat digambarkan dalam gambar 1 .

Hipotesis. Berdasarkan landasan teori dan penelitian terdahulu, maka Hipotesis dalam penelitian ini adalah sebagai berikut: $\mathrm{H}_{1}$ : Kecanggihan teknologi informasi berpengaruh positif terhadap efektivitas sistem informasi akuntansi pada hotel berbintang tiga dan empat di kota Semarang.

$\mathrm{H}_{2}$ : Partisipasi manajemen berpengaruh positif terhadap efektivitas sistem informasi akuntansi pada hotel berbintang tiga dan empat di kota Semarang. 
Tabel 1

Ringkasan Penelitian Terdahulu

\begin{tabular}{|c|c|c|c|}
\hline No & $\begin{array}{c}\text { Peneliti dan } \\
\text { Tahun }\end{array}$ & Variabel & Hasil \\
\hline 1. & $\begin{array}{l}\text { Ratnaningsih \& } \\
\text { Agung } \\
(2014)\end{array}$ & $\begin{array}{l}\text { Independen: Kecanggihan } \\
\text { Teknologi Informasi, Partisipasi } \\
\text { Manajemen, dan Pengetahuan } \\
\text { manajer akuntansi } \\
\text { Dependen: Efektivitas Sistem } \\
\text { Informasi Akuntansi }\end{array}$ & $\begin{array}{llr}\text { Kecanggihan } & \text { teknologi } & \text { informasi, } \\
\text { partisipasi } & \text { manajemen, serta } \\
\text { pengetahuan } & \text { manajer akuntansi } \\
\text { berpengaruh positif terhadap sistem } \\
\text { informasi } \\
\text { akuntansi. }\end{array}$ \\
\hline 2. & $\begin{array}{l}\text { Ismail } \\
\text { (2009) }\end{array}$ & $\begin{array}{l}\text { Independen: Kecanggihan } \\
\text { Teknologi, Partisipasi Manajer, } \\
\text { dan Pengetahuan Manajer } \\
\text { Dependen: Efektivitas Sistem } \\
\text { Informasi Akuntansi }\end{array}$ & $\begin{array}{l}\text { Kecanggihan teknologi berpengaruh } \\
\text { negatif terhadap sistem informasi } \\
\text { akuntansi }\end{array}$ \\
\hline 3. & $\begin{array}{l}\text { Anantawikrama } \\
\& \text { Nyoman } \\
(2014)\end{array}$ & $\begin{array}{l}\text { Independen: Pengetahuan } \\
\text { Karyawan bagian Akuntansi, } \\
\text { Pemanfaatan Teknologi, dan } \\
\text { Partisipasi Manajemen } \\
\text { Dependen: Efektivitas Sistem } \\
\text { Informasi Akuntansi }\end{array}$ & $\begin{array}{l}\text { Pengetahuan karyawan } \\
\text { akuntansi, pemanfaatan } \\
\text { informasi dan partisipasi manajemen } \\
\text { berpengaruh positif terhadap terhadap } \\
\text { efektivitas sistem informasi } \\
\text { akuntansi. }\end{array}$ \\
\hline 3 & Komala (2012) & $\begin{array}{l}\text { Independen: } \quad \text { Pengetahuan } \\
\text { Manajer Akuntansi dan } \\
\text { Partisipasi Manajemen } \\
\text { Dependen: Kualitas Sistem } \\
\text { Informasi Akuntansi }\end{array}$ & $\begin{array}{l}\text { Pengetahuan manajer akuntansi dan } \\
\text { partisipasi manajemen berpengaruh } \\
\text { positif terhadap kualitas sistem } \\
\text { informasi akuntansi. }\end{array}$ \\
\hline
\end{tabular}

Sumber : Review Jurnal (2019)

\section{Gambar 1}

Kerangka Teoritis

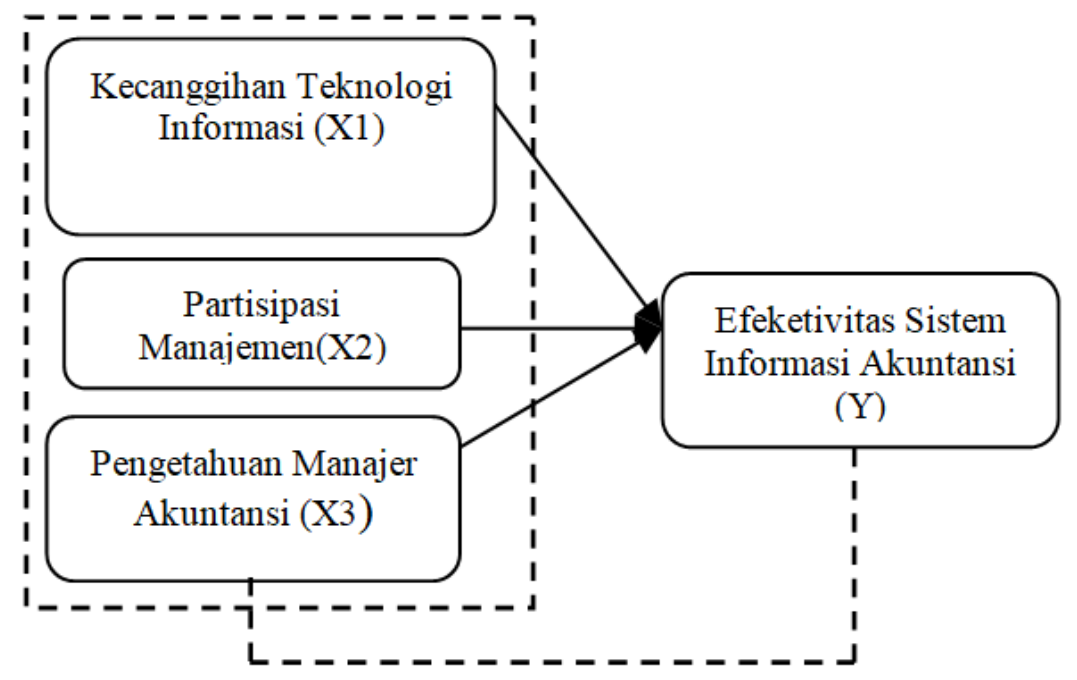


$\mathrm{H}_{3}$ : Pengetahuan manajer akuntansi berpengaruh positif terhadap efektivitas sistem informasi akuntansi pada hotel berbintang tiga dan empat di kota Semarang Partisipasi manajemen berpengaruh positif terhadap efektivitas sistem informasi akuntansi pada hotel berbintang tiga dan empat di kota Semarang.

\section{METODE PENELITIAN}

Jenis Penelitian. Penelitian ini merupakan penelitian kuantitatif. Yaitu suatu metode yang berusaha mengumpulkan, menyajikan, serta menganalisis data sehingga dapat memberikan gambaran yang jelas mengenai objek yang diteliti.

Definisi Operasional. Berikut ini definisi operasional untuk masing-masing variabel yang digunakan dalam penelitian:

\section{Efektifitas Sistem Informasi Akuntansi}

\section{(Y)}

Manfaat informasi akuntansi pertanggung jawaban dalam sistem tradisional dapat berupa informasi masa lalu atau historis dan dapat berupa informasi yang akan datang. Informasi masa lalu bermanfaat untuk menilai kinerja manajer pusat pertanggungjawaban dan untuk memotivasi manajer.

Dimensi dan indikator dari efektifitas Sistem Informasi Akuntansi adalah :

a. Pengelolaan efektifitas dengan acara mengarahkan usaha manajer dengan indikator :

- Sistem informasi yang terkomputerisasi yang digunakan perusahaan memiliki sistem yang tinggi.

- Sistem informasi yang digunakan perusahaan telah menghasilkan laporan keuangan secara tepat waktu dan akurat.
- Sistem informasi akuntansi yang digunakan perusahaan mampu meningkatkan produktifitas sebagai pekerja dan akuntan perusahaan.

- Sistem informasi akuntansi yang digunakan perusahaan mampu meningkatkan efektifitas layanan bagi pelanggan

b. Pengelolaan efektifitas dengan cara mengurangi biaya

Sistem informasi akuntansi yang digunakan perusahaan mampu meningkatkan kualitas laba yang dihasilkan.

\section{Kecanggihan Teknologi $\left(\mathrm{X}_{1}\right)$}

Kecanggihan teknologi informasi adalah kegunaan kecanggihan TI menyebabkan informasi lebih tersedia dan lebih cepat untuk didapatkan, termasuk informasi ekesternal, informasi internal dan informasi yang sudah ada sebelumnya, sehingga dapat meningkatkan aksesibilitas atau keterjangkauan informasi.

Dimensi dan indikator dari Kecanggihan Teknologi Informasi adalah Kecanggihan teknologi informasi dengan indikator :

- Sistem informasi di perusahaan di dukung oleh internet, sistem database, sistem pendukung keputusan dan aplikasi akuntansi.

- Sistem informasi akuntansi di perusahaan memiliki sistem informasi akuntansi utama, seperti : general legder, kode rekening, jurnal dan bukti transfer.

- Sistem informasi yang terkomputerisasi yang digunakan perusahaan sudah didukung perangkat keras dengan spesifikasi canggih.

- Software akuntansi yang digunakan perusahaan dil lengkapi fitur yang lengkap dan waktu respon yang cepat.

- Software akuntansi yang digunakan perusahaan mampu memproses transaksi 
dalam volume besar dan menghasilkan informasi yang akurat

\section{Partisipasi Manajemen $\left(X_{2}\right)$}

Partisipasi manajemen dikonseptualisasikan sebagai keterlibatan dan partisipasi eksekutif. Dimensi dan indikator dari

a. Keterlibatan eksekutif di bidang teknologi informasi dengan indikator :

- Manajemen dilibatkan dalam memilih hardware dan software

- Manajemen dilibatkan dalam penyelesaian masalah selama implementasi sistem informasi akuntansi perusahaan

- Manajemen dilibatkan dalam perencanaan pengembangan sistem dimasa yang akan datang

b. Partisipasi eksekutif dibidang teknologi informasi dengan indikator :

- Manajemen berpartisipasi dalam implementasi sistem informasi dalam perusahaan.

\section{Pengetahuan Manajer Akuntansi $\left(\mathbf{X}_{3}\right)$}

Manajer akuntansi merupakan eksekutif yang mengkoordinasikan partispasi manajemen dalam perencanaan dan pengendalian untuk mencapai target perusahaan, khususnya untuk menentukan efektivitas implementasi kebijakan, mengembangkan struktur dan prosedur organisasi

Dimensi dan indikator dari Pengetahuan Manajer Akuntansi adalah :

a. Perencanaan untuk mencapai target dengan indikator :

- Memahami pengolahan data dengan menggunakan sistem komputer akuntansi.

- Mengetahui data basis atau kumpulan informasi yang disimpan di dalam komputer secara sistematik sehingga dapat diperiksa menggunakan suatu program komputer.

- Memahami proses pengumpulan, menyiapkan informasi dalam bentuk catatan, laporan dan analisis pekerjaan dengan menggunakan lembar lajur.

b. Pengendalian untuk mencapai target dengan indikator :

- Mengetahui teknologi aplikasi akuntansi yaitu perangkat lunak yang mencatat semua transaksi akuntansi.

- Mengetahui efektifitas dan efisiensi penggunaan komputer terintegrasi yang berdampak terhadap penghematan pengeluaran perusahaan.

- Mengetahui sistem komputer yang mendukung manajemen, e-mail, dan internet sistem

Populasi dan Sampel. Populasi dan Sampel dalam penelitian ini adalah manajer akuntansi hotel berbintang tiga dan empat di kota Semarang sebanyak 130 manajer.

Jenis Data. Jenis data yang digunakan adalah data primer. Data primer merupakan data yang diperoleh secara langsung dari sumber asli (tidak melalui media perantara) (Supomo, 1999).

Teknik Pengumpulan Data. Teknik pengumpulan data yang dilakukan dalam penelitian ini adalah kuesioner yang dibagikan secara langsung pada manajer akuntansi hotel berbintang tiga dan empat dikota Semarang.

Teknik Analisis Data. Metode analisis data yang digunakan adalah analisis regresi linear berganda

\section{HASIL DAN PEMBAHASAN}

Deskripsi Data. Dari 130 kuesioner yang dibagikan kepada responden, ternyata hanya 97 yang kembali. Dari 97 kuesioner yang kembali terdapat 17 kuesioner yang tidak dapat diolah atau rusak, sehingga jumlah data yang dapat diolah sebesar 80 .

Berdasarkan Jenis kelaminnya, jumlah responden pria sebanyak 63 dan wanita 33 
orang. Sedangkan jika dilihat dari usianya, maka hanya 2 orang yang memiliki usia di bawah 30 tahun, 19 orang yang berusia diantara 31-35 tahun, dan 75 orang berusia di atas 35 tahun. Berdasarkan tingkat pendidikan, ternyata masih ada manajer akuntansi yang berpendidikan Diploma (D3) sebanyak 3 orang, sedangkan yang bergelar master (S2) baru 5 orang, dan sisanya 88 orang berpendidikan sarjana (S1).

Hasil Uji Analisis Regresi Linier Berganda. Berdasarkan hasil uji analisis regresi linier berganda diperoleh hasil seperti yang tercantum pada tabel 2 .

Berdasarkan tabel 2 tersebut dapat disusun rumus regresi sebagai berikut:

$$
\hat{Y}=6.765+-0.001 X_{1}+0.146 X_{2}+0,445 X_{3}
$$

Uji Hipotesis. Berdasarkan hasil uji regresi pada tabel 2, maka dapat dilakukan uji hipotesis sebagai berikut:

Variabel kecanggihan teknologi (X1) tidak berpengaruh terhadap efektivitas system informasi akuntansi (Y) dengan nilai t sebesar -0,015 (negatif) dan signifikansi sebesar 0,988 .

Tabel 2

Hasil Uji Regresi Linier Berganda

\begin{tabular}{cccccc}
\hline Model & \multicolumn{2}{c}{$\begin{array}{c}\text { Unstandardized } \\
\text { Coefficients }\end{array}$} & $\begin{array}{c}\text { Standardized } \\
\text { Coefficients }\end{array}$ & $\mathrm{t}$ & \multirow{2}{*}{ Sig. } \\
\cline { 2 - 5 } & $\mathrm{B}$ & Std. Error & Beta & & \\
\hline (Constant) & 6.765 & 1.602 & & 4.222 & .000 \\
X1 & -.001 & .089 & -.002 & -.015 & .988 \\
X2 & .146 & .143 & .163 & 1.017 & .312 \\
X3 & .445 & .119 & .520 & 3.742 & .000 \\
\hline
\end{tabular}

Sumber: Data primer yang diolah, 2020

Tabel 3

Uji Koefisien Determinasi

\begin{tabular}{ccccc}
\hline Model & $\mathrm{R}$ & R Square & Adjusted R Square & Std. Error of the Estimate \\
\hline 1 & $.654^{\mathrm{a}}$ & .427 & .405 & 2.074 \\
\hline
\end{tabular}

Sumber : Data primer yang diolah, 2020

Variabel partisipasi manajer (X2) tidak berpengaruh terhadap efektivitas system informasi akuntansi ( $\mathrm{Y}$ ) dengan nilai $\mathrm{t}$ sebesar 1,017 (positif) dan signifikansi sebesar 0,312.

Variabel pengetahuan manajer akuntansi (X3) berpengaruh terhadap efektivitas system informasi akuntansi (Y) dengan nilai t sebesar 3,742 (positif) dan signifikansi sebesar 0,000 .

Uji Koefisien Determinasi. Uji koefisien determinasi digunakan untuk mengetahui seberapa besar kombinasi variabel indepen- den (X1, X2, dan X3) mampu menjelaskan variabel dependen (Y).

Berdasarkan hasil uji koefisien determinasi diperoleh nilai adjusted $\mathrm{R}$ square sebesar 0,405; yang artinya kombinasi antara kecanggihan system informasi, partisipasi manajemen, dan pengetahuan manajer akuntansi; mampu menjelaskan efektivitas system informasi akuntansi sebesar 40,5\% sedangkan sisanya dijelaskan oleh variabel lain di luar model penelitian ini. 
Pembahasan Pengaruh Kecanggihan Teknologi Terhadap Efektivitas Sistem Informasi Akuntansi. berdasarkan hasil penelitian, diketahui bahwa variabel kecanggihan teknologi informasi $\left(\mathrm{X}_{1}\right)$ secara statistik tidak berpengaruh terhadap efektivitas sistem informasi akuntansi (Y). Dengan demikian tidak mampu menerima hipotesis yang menyatakan bahwa kecanggihan teknologi informasi berpengaruh terhadap efektivitas sistem informasi akuntansi pada hotel berbintang tiga dan empat di kota Semarang. Kecanggihan teknologi informasi tidak mempengaruhi efektivitas sistem informasi akuntansi dalam penelitian ini karena sebagian besar perusahaan masih menggunakan sistem akuntansi manual daripada menggunakan sistem informasi akuntansi berbasis komputer. Sistem informasi akuntansi memiliki sistem informasi utama, seperti jurnal umum, kode rekening, dan bukti transfer di nilai kurang terintegrasi sehingga tidak berpengaruh terhadap efektivitas

Penelitian ini sejalan dengan Nabizadeh (2014), yang menyatakan bahwa kecanggihan tekonologi informasi tidak berpengaruh terhadap efektivitas sistem informasi akuntansi.

Pembahasan Pengaruh Partisipasi Manajemen Terhadap Efektivitas Sistem Informasi Akuntansi. Berdasarkan hasil penelitian, diketahui bahwa variabel partisipasi manajemen $\left(\mathrm{X}_{2}\right)$ secara statistik tidak berpengaruh terhadap Efektivitas Sistem Informasi Akuntansi (Y). Dengan demikian tidak mampu menerima hipotesis yang menyatakan bahwa Partisipasi Mana-jemen berpengaruh terhadap Efektivitas Sistem Informasi Akuntansi pada hotel berbintang tiga dan empat di kota Semarang.

Partisipasi mengandung makna adanya keterlibatan para karyawan dalam aspekaspek mental dan emosional yang men- dorong mereka untuk berkontribusi dalam pencapaian tujuan perusahaan. Bentuk partisipasi ini seharusnya merupakan proses komunikasi atau teknik mendapatkan dan memanfaatkan umpan balik dari karyawan dalam pengambilan keputusan. Namun dalam hal ini pihak karyawan tidak memiliki otoritas mengambil keputusan.

Hasil penelitian ini mendukung penelitian Ferdianti (2017) yang menyatakan bahwa partisipasi manajemen tidak berpengaruh pada efektivitas sistem informasi akuntansi.

Pembahasan Pengaruh Pengetahuan Manajer Akuntansi Terhadap Efektivitas Sistem Informasi Akuntansi. Berdasarkan hasil penelitian, diketahui bahwa variabel pengetahuan manajer akuntansi $\left(\mathrm{X}_{3}\right)$ secara statistik berpengaruh terhadap efektivitas sistem informasi akuntansi (Y). Dengan demikian menerima hipotesis yang menyatakan bahwa pengetahuan manajer akuntansi berpengaruh positif terhadap efektivitas sistem informasi akuntansi pada hotel berbintang tiga dan empat di kota Semarang.

Hal ini sesuai dengan Statement Gerrion (2012) yang menyatakan bahwa manajer akuntansi merupakan salah satu anggota manajemen puncak yang berperan aktif dalam perencanaan, pengendalian dan pengambilan keputusan yang akan mempengaruhi perusahaan secara keseluruhan.

Hasil penelitian ini sejalan dengan Kadek (2014) yang membuktikan bahwa pengetahuan manajer akuntansi berpengaruh terhadap efektivitas sistem informasi akuntansi.

\section{SIMPULAN}

Kesimpulan. Berdasarkan hasil analisis dan pembahasan dapat ditarik kesimpulan sebagai berikut : 
1. Kecanggihan Teknologi Informasi $\left(X_{1}\right)$ tidak berpengaruh terhadap Efektivitas Sistem Informasi Akuntansi (Y)

2. Partispasi Manajemen $\left(\mathrm{X}_{2}\right)$ tidak berpengaruh terhadap Efektivitas Sistem Informasi Akuntansi (Y)

3. Pengetahuan Manajer Akuntansi $\left(\mathrm{X}_{3}\right)$ berpengaruh positif signifikan terhadap Efektivitas Sistem Informasi Akuntansi (Y)

Saran. Berdasarkan uraian dari analisa dan pembahasan, maka saran yang dapat diberikan dalam penelitian ini adalah sebagai berikut :

1. Saran bagi bisnis perhotelan. Hasil penelitian ini menunjukkan bahwa variabel Pengetahuan Manajer Akuntansi memiliki kontribusi yang besar terhadap Efektivitas Sistem Informasi Akuntansi. Oleh karena itu, hendaknya pengetahuan manajer akuntansi harus selalu dievaluasi dan ditingkatkan untuk pencapaian tujuan perusahaan secara maksimal. Hal tersebut dapat dilakukan dengan cara: pelatihan, pengembangan pendidikan terkait, dan pemberian informasi lainnya yang dilakukan secara terus menerus oleh pihak perusahaan.

2. Saran untuk penelitian selanjutnya. Penelitian selanjutnya diharapkan dapat menguji variabel lainnya seperti program pelatihan dan pendidikan pengguna sistem informasi akuntansi serta kemampuan teknik personal yang mempunyai kemungkinan berpengaruh terhadap efektivitas sistem informasi akuntansi.

\section{DAFTAR PUSTAKA}

Ann Mooney, Michael Mahoney, and Barbara Wixom. 2008. Achieving Top

Management Support in Strategi Technology Initiatives. Howe School Alliance For Technology Management, 12 (2), pp: 1-3.

Bodnar, George H. dan William Hopwood S. 2000. Sistem Informasi Akuntansi. Jakarta: Salemba Empat.Dirgayusa

Ghozali, Imam, 2011. Aplikasi Analisis Multivariate Dengan Program IBM SPSS 19, Edisi 5. Semarang: Badan Penerbit Universitas Diponegoro.

Hall, James. A. 2001. Sistem Informasi Akuntansi. Salemba Empat

Indriantoro, Nur, 1999. Metodologi Penelitian Bisnis. Yogyakarta: BPFE

Sukma Putra, Anantawikrama Jogijyanto, 2000. Sistem Informasi Berbasis Komputer.Edisi Kedua.Yogyakarta :BPFE

Dwitrayani, Made Christin. 2012. Pengaruh Kecanggihan TI dan Partisipasi Manajemen terhadap Efektivitas Sistem Informasi Akuntansi BPR di Kabupaten Badung.

Sukma. Putra, Anantawikrama Widjajanto, Nugroho. 2001. SistemInformasi Akuntansi. Jakarta : Erlangga 